\title{
FROM DARK HELMET TO KYLO REN
}

\section{Charting the Tragic Trajectory of Fascistic Fans and Franchise Fascism}

\section{Garret Castleberry}

\section{Abstract:}

This essay examines the culture circulating around late twentieth century and early twenty-first century media franchising with special emphasis on the Star Wars film canon. It charts the emergence of fan studies as one way in which scholars may assess, investigate, and theorize about audience responses to film franchises like Star Wars. It places special emphasis on anti-fan behaviors, introducing the dualistic terms fascistic fandom and franchise fascism as ways to denote the increased intensity of industry practices and fan resistance. Ultimately, I contend that parodic entertainments like Mel Brooks's satirical sci-fi features Spaceballs use the lens of comedy to accurately predict the zealous movement of large Hollywood studios toward a franchise-based distribution model. Furthermore, Disney's acquisition and subsequent mass distribution of Star Wars as an inclusive and ongoing transmedia global franchise presents a twenty-first century case study in understanding franchise fascism as an important primer to anti-fan behaviors.

Keywords:

Star Wars, Fascism, Fandom

The year 2015 marked a point in time that saw the return of the ultimate fan text and megafranchise, Star Wars. Fueled by speculation following Disney's multi-billion dollar acquisition of LucasFilm a few years prior, the news spread like wildfire across the galaxy. A prophecy foretold of a Brave New Order in which Jedi-esque "auteur talents" would rise, including the likes of J.J. Abrams, Rian Johnson, and that guy (with no proven track record) who resurrected the Jurassic Park movies. In a coup of Hollywood blockbuster necromancy, the franchise would be freed from the dictatorial clutches of an out-of-touch George Lucas, a Yoda-like hermit of sorts who would fade into obscurity like a Jedi succumbed to the force, only to periodically return and tinker with 
his magical properties like a Jedi ghost steering the trajectory of pop history. With the Star Wars prequels (1999-2005) and Indiana Jones and the Kingdom of the Crystal Skull (2008) respectfully, it is inaccurate to consider that each of these "returns" weren't successful. If pop culture has succeeded in becoming secular world religion, then these respective callbacks drew masses back again to gaze within the allegorical well, and the stories spun there still translated into billions of dollars in box office, home video, and merchandizing revenue. But it wasn't enough. Cycles are inevitable. In the society of the spectacle, as Guy DeBord famously named it, even democratic free market consumers have a breaking point. The people demanded a new king. And the happiest entertainment oligarchy on earth was more than ready to oblige their unprecedented celebration by emboldening a new world order for these culturally revered and financially commodified simulacral myths.

This essay examines the role Star Wars plays as a "dominant-hegemonic position" of cultural persuasion. In his essay "Encoding/Decoding”, Stuart Hall hypothesizes mass media culture in which a "viewership" or audience-consumer base "decodes the message in terms of the reference code in which it has been encoded" operating within the "hegemony of the dominant code." And yet, amid the Utopic presence of never-ending sequels, storylines, and collectibles, a dark side festers beneath the surface of paradise. I identify two strands of fascistic behavior that react in concert with Star Wars' rhythmic cycles. ${ }^{2}$ On one side, devout fandoms have always inculcated pockets of sentimental resistance. ${ }^{3}$ This is a natural demonstration of "creative difference" encoded into the human spirit. At the same time -- like no other time -- the digital age provides a unifying platform allowing creative dissenters to swarm and reform in constantly-shifting coalitions, ever in search of a new motivating critical impulse. On the other side, the Hollywood film industry has experienced unparalleled global profitability in recent years, achieving not only elite market presence among publicly traded companies but also peak social persuasion as a leading American export.4 However, tensions persist. Despite surging global popularity with mega-franchise super-heroic brands like Marvel, Transformers, and Star Wars, domestic box office ticket sales continue to decline in the U.S. mecca of multi-platform mass media. Or do they? 5 Perhaps the rise in aggressive resentment partially belongs to increasingly homogenized formulas and added emphasis on politically correct multicultural representation leading to a perceived brand of ubiquitous entertainment. Ubiquitous entertainment, as the new ethno-neutral American pastime, has become a preset standard encoded into everyday American life practice. To disrupt the perceived flow-to challenge "the way things should be" from the perspective of those who gaze into the well-invites dissent. In a fictitious universe brimming with laser swords and indentured droids, the well stares back (reflecting the ides of a fundamental change) whether we wanted it or not.

In the following sections, I chart a creative and sociological path of fascistic behavior rooted in the tensions between aggressively vocal fandom in one corner and the tendency toward tightly controlled studio systems in the other. I argue that in addition to the fascistic themes baked into the original Star Wars narrative, later offshoots like Mel Brooks's film parody Spaceballs, the toy culture surge coinciding with Lucas's prequel trilogy, and the more recent mixed reactions to the Disney-sponsored soft reboot of the Star Wars franchise, each prophecy and promote an interrelated phenomenon identifiable not merely as fan but also franchise fascism: an irresistibly powerful production process tethered closely to business imperatives over artistic initiatives, simultaneously generating an illiberal yet economically significant meta-resistance amid technologically empowered and critically dissenting consumers. 


\section{The Hollywood Industry as a Mass Media Model of Communication}

Hollywood, as the manufacturer of celluloid dreams, historically leans toward conservative decision-making practices as a means to thrive economically first, culturally second. ${ }^{6}$ This system has produced iconic films but is structurally committed to the premise that profitability derives more consistently from conservative repetition than iconoclastic innovation. Meanwhile, the consumer voice is a relatively recent paradigm shift in the history of advertising. The twentieth century top-down philosophy housed a consumer model that allowed producers primary control over content. An ad tells the consumer what they "need", and the audience-reader-consumer senses being "hailed" and in turn agrees to terms or rejects the product.7 This producer-toconsumer economic model closely reflects the history of mass media. In the field of communication studies, mass mediated communication is understood as a one-to-many model of communication. The message in an exchange carries from one central location to many receivers. It is a top-down mode of communication exchange and one that intentionally works in a one-sided direction that suggests overwhelming power on the part of the producer.

The top-down model of communication retains a majority of persuasive power for the source of the communiqué, in this instance the medium of film. Similar mediums in mass media history follow this one-to-many flow of information exchange, including print publishing, radio, and television. There are numerous benefits to this technocratic model, chief among them the ability of free market enterprise to also benefit a democratic society through the diffused transmission of national messages and unified information. If the rise in popular culture teaches us anything, it is also that mass media holds enormous transformative potential socially, culturally, and politically. Mass media thus posits a cautionary tale whenever groups or governments-nefarious or otherwise-control, manipulate, or abuse the innate influence of mass media. In an ideal democratic system, alternative mass media in the form of news and the press function as the proverbial "fourth estate" gatekeepers charged with accountability to all constructs of power. This distinguishes U.S. mass media and much of the Western democratized nation-states as functioning in a kind of quasi-ethical pseudo-balance. At least in theory if not in practice.

\section{Fan Engagement as a Reader-Response Opportunity to Mass Media(ate)}

Fan Studies emerged as a preeminent sub-discipline within Media Studies in the late twentieth and early twenty-first century. Waves of fan engagement have been prevalent dating back to the mid-century emphasis on data analysis of media effects. The inconclusive results of quantitative assessment over decades suggested a need for deeper penetration, not only from social scientists, but also a broad spectrum of qualitative ethnographers and critical-cultural scholars. Paralleling the emergence of Television Studies-each only a couple of decades after the arrival of Film Studies-specific interest in fans and fan communities serves as a robust offshoot to what was initially only referenced under Audience/Reception Studies. Space and content restriction for this essay limits any full literature review regarding these significant coordinating disciplines (nor is there time-space enough to stop and humor at era-specific terminology like "New Media"), but in terms of intellectual context, these waves each advance how we assess the splintering impacts of mass media individual and collective levels. 
Not surprisingly, Fan Studies is brimming with special interest research, primarily because it also affords scholars of popular culture an opportunity to inquisitively interrogate their own cultural desires no matter how obscure or bizarre. This is the inquisitor's response to the nature of art, or rather, the tension Kenneth Burke calls "art under capitalism" also theorized by Walter Benjamin and later collected into The Work of Art in the Age of Mechanical Reproduction. It is no coincidence that both scholars play formidable roles in helping shape the Critical Turn in midtwentieth century academia alongside the bevy of resistance-esque theorists and immigrants that collectively formed the Frankfurt School of Germany and later the Centre for Contemporary Cultural Studies in Birmingham, England. These resistance fighters felt the full force of political fascism and an age of rapid Western expansion in postwar Europe and America. Despite their collective reservations linked notoriously to wartime conditions and postwar melancholia, a new wave of softer, gentler reader-response to pop culture emerges against the hybridized backdrop between Baby Boomer youth culture transitioning to Generation X creativity. Henry Jenkins, already an active scholar throughout the 1980s, emerges in the 1980s and 90s as the pop media scholar de jour with special interest in the ethnographic happenings of fans and fan communities. ${ }^{8}$ By the late 90 , the growing trend of "New Media" scholars collapsed many traditional boundaries just as the Internet began collapsing traditional boundaries between mass mediums.

By the end of the decade, Fan Studies found footing through its core strength as an interdisciplinary odyssey that bridged interest groups across media and mediums. Matt Hills's Fan Cultures ${ }^{9}$ strengthened the argument against classical media effects theories, demonstrating the diversity embodied by faction-friendly fan communities. That is to say, not necessarily friendly factions but a wide net of competing, contrasting, and essentially co-existing communities of pop culture tribes; inhabitants stretching across the far-flung reaches of the would-be "global village". ${ }^{10}$ In the 2000 s and 2010s, fan studies explodes directionally in a number of key directions. The edited anthology Fandom: Identities and Communities in a Mediated World (now in its second edition) best embodies a "super team up" anthology that exhibits the full breadth of first-wave critical fan studies as a multi-methodological insight into a subject previously recognized as an Object by advertisers and the media industry writ large. ${ }^{11}$ Lynn Zubernis and Katherine Larsen view acts of fandom as a movement at a "crossroads" 12 pinpointing the cynical turn in online media behavior as social media allows unparalleled access to celebrities representative in all spheres of public notoriety and social influence. Mark Duffett's work recognizes the pedagogical value afforded by fan studies ${ }^{13}$ just as Melissa Click provides a seminal contemporary voice in the field, contributing behind various paywalls while also negotiating broader access through works like The Routledge Companion to Media Fandom. ${ }^{14}$ Click's most recent collaborative effort unites leading voices in the field to tackle the underbelly phenomenon dubbed Anti-Fandom: Dislike and Hate in the Digital Age ${ }^{15}$, which parallels the contemporary interest of this essay. There are, increasingly, dozens of new articles and essays each year that expand upon the foundations of fan studies and their links to broader interest groups and divisions. To follow all these threads, and others, would exceed the limits of this format. Reducing a wider range of literature for purposes specific to the scope and argument of this analysis, these examples are sufficient to substantiate the emergence of empowered fandom as a new force that fundamentally alters how media (and films in particular) are conceived, created, produced, marketed, and distributed. 


\section{Fan Dissent as an Oppositional Decoding Model of Mass Communication}

In his seminal essay "Encoding/Decoding", Stuart Hall expands the normative range of the traditional communication model in which a sender sends a message to a receiver along a channel, where it is then processed in a simultaneous exchange of responses. Hall theorizes a spectrum of interpretive responses that he calls decoding. These receiver responses include a dominanthegemonic decoding of a person, text, or producer's intended meaning, a negotiated meaning that straddles intended/unintended interpretation, and the oppositional meaning of a text, which suggests a rejection of or reinterpretation to the communicated message. The theorized reading of anti-fans assumes a shared definition of what constitutes a fan to begin with. A fan is distinct from an audience member or casual consumer in terms of their relational approach to cultural artifacts - a film, television series, comic book, toy line, album, et al. The artifact, through its highly persuasive encoding, places a spell on the consumer in a way that simulates organic connection, even though most cultural artifacts are manufactured for mass consumption (e.g. non-unique). ${ }^{16}$

Fascistic Fans, I argue, act collectively in much the same way as meddling studio executives, intent on inserting broad campaigns built to fulfill impossible conditions of pop culture mimesis. Both factions effectively neuter the creative genius, the jouissance of the auteur's vista. ${ }^{17}$ This scope of creativity ends up closely resembling a fence, sharply constructed of pointy white pickets, more interested in insulation and reproducible experience. Why seek out the nectar of the gods when we already have Coca-Cola? ${ }^{18}$

\section{The Prophecy of the Fascist Franchise Parodied in Mel Brooks' Spaceballs}

Arguably, Star Wars played the largest role ushering in a paradigm shift in production practices alongside other summer blockbusters like Jaws, The Exorcist, Close Encounters of the Third Kind, Superman: The Movie, and populist entertainments of the New Hollywood movement. ${ }^{19}$ The profitability of the few helped reshape, slowly at first but increasingly over time, production practices that include what constitutes a "tent pole" feature (big budget + strategic release window + visual effects +/- A-list casting). By the close of the 1970s, the New Hollywood cabal of blockbuster auteurs (Coppola, Scorsese, Spielberg, Lucas, Donner, etc.) cemented a turning of the guard that drove audiences back to cinema in a period when movie houses and drive-ins began dying off just as indoor and outlet malls erected multi-screen cineplex's. ${ }^{20}$

The emergence of the American mall as a social hub and cultural marker represents a powerful visual symbol of economic life in 1980s America. Harkening symbols of capitalism created physical space for moviegoers either directly or in the popular imaginary while ushering in an age of excess. From fluorescent bulbs lighting food courts and parking lots to fountains intended to absorb disposable income, visual markers signified a paradigm shift in consumer confidence. The mall store also offered new ways to consume the tertiary aspects of New Hollywood and the blockbuster feature. Brick-and-mortar businesses ranged from toy stores (K.B. Toys) to clothing outlets (novelty T-shirts, sweaters, tie-ins) and department stores (Sears, J.C. Penny, Montgomery Ward). Furthermore, print cataloguing also reinforced the value these physical spaces provide, mailing out full-color catalogs in excess of 500-700 pages at Christmas season. ${ }^{21}$ 
Even as a direct market initiative, while seemingly bypassing physical mall spaces the department store catalogue still helped secure America's shopping mall presence as a secular Mecca for holiday consumers.

If the landscape of the U.S. in any way shifted toward booming interest in pop culture properties, both intellectual and material, then Star Wars led the way once again with nearly a decade of dominant toy sales and zeitgeist influence. Even the ultra-conservative Reagan Administration adopted a Cold War/Space Race policy colloquially dubbed the "Star Wars" program. Just as popular culture by definition represents a mass produced and mass consumed property with broad user interest and profitable producer gains, Star Wars arguably forged a fascistic presence that would impact the future narrow scope of Hollywood production slates, shifts from industry production budgets toward tent pole synergy, and the hegemony of franchise profits over artistic integrity (e.g. auteur protections). To that end, Mel Brooks's (1987) sci-fi satire Spaceballs orbited the Star Wars stratosphere like the incandescent tail to Haley's Comet. With his largest production budget to date, rumored to be close to $\$ 34$ million, Brooks essentially spent three times the cost of Lucas's original Star Wars. To the parody film's credit, the budgetary results are almost entirely on display visually. A master of genre parody, Brooks and his production team poor their labor into lavish reproductions of key set pieces, including an enormous multi-scene Star Destroyer-like bridge room and the Millennium Falcon-esque "Eagle 5 " Winnebago piloted by Lone Starr (Bill Pullman) and Barf (John Candy). Much has been written about Brooks's career including how his peak works coincide with the New Hollywood era in the 1970s. ${ }^{22}$ Not only did New Hollywood reset the table in terms of dictating how tent pole productions would come to dominant the cinescape, but Brooks' keen application of satire help caricature through stereotype just how absurdly fascistic this new regime could be.

While Spaceballs operates as an ensemble comedy, Dark Helmet (peak Rick Moranis) elevates every scene in which the character appears, a testimony to the fascistic inversion to Darth Vader's pop culture omnipresence as much as a combination of Brooks's script (co-written by Thomas Meehan and Ronny Graham) and Moranis's line reads and physical comedy. In the DVD commentary, Brook admits to Moranis and he largely improvising the Dark Helmet "playing with this Spaceballs toys in private" scene-an uproarious send-up of and harbinger to man-child syndrome synonymous with stereotypical comic book culture. While the man-child persona is often depicted through stereotypic performances akin to the works of Adam Sandler or Seth Rogen (see also The Simpsons's Comic Book Guy), the arrested development of white male youth culture in America has taken considerable hits from intellectuals, celebrities, politicians, and many engaged in public sphere discourse. What Dark Helmet exhibits in terms of man-child buffoonery and space-based shenanigans arguably becomes inverted yet again with comic-less scorn by Aiden Christianson's performance as pre-Vader Anakin Skywalker in Star Wars Episodes II and III: Attack of the Clones (Lucas, 2002) and Revenge of the Sith (Lucas, 2005) respectively.

Arguably, Moranis's comically adolescent Dark Helmet projects even more toward the postDisney era and Adam Driver's rendition of Kylo Ren/Ben Solo. Ren's “emo"-laden outbursts include his irresponsible slashing of computer boards with his lightsaber in J.J. Abrams's 2015 Star Wars: The Force Awakens and self-aware insecurity with his own Vader-like helmet when prompted by Rey and later by Supreme Leader Snoke in Rian Johnson's Star Wars: The Last Jedi in 2017. These two examples seemingly break the fourth wall in the way they overtly play with sacred signs and symbols in Star Wars canon. Unlike Christianson's Anakin, Driver's Ren holds 
rich potential for deepening the mimetic ways in which Star Wars succeeds at copying postwar generations in the U.S. His "emo" persona (as it is labeled by some online) fits into Millennial characteristics of entitled youth. As pure villain with heroic family roots, Kylo also offers the perfect semiotic stand-in for someone born into techno-first world without any understanding of the moral consequences or work ethic built up by previous generations. He desires instant gratification, which he commands through roguish use of the force. One could postulate that Ren desires to be a corporate vice president without paying said dues, but the reality is he longs to be CEO before age 30. Framing his characterization against the shadow of aggressive white privilege is not only the "easy" interpretation to make; it is virtually the only reading directors Abrams and Johnson allow in Episode VII and VIII. It is no wonder then that for the third consecutive trilogy, Star Wars marketers are further tasked with promoting dark supervillains as the ultimate toy line object or Halloween costume/cosplay character to collect. Think Kylo Ren's red tri-tipped lightsaber isn't the number one selling toy (non-LEGO) since 2015? If so, I have some real estate on Alderaan that I would like to sell you. Like the Nazi uniforms notoriously designed by Hugo Boss, the Sith Lord and Stormtrooper uniforms are simply "too cool" to hate. Thus, the ideological conflict consumers wrestle with, largely at an unconscious level.

In The Political Mel Brooks, a link is argued between the parodic prophecies found in Mel Brook's work-especially the Schwartz-based "merchandizing!" den-and the fascistic qualities both Spaceballs and Star Wars draw upon from WWII Germany. More than political parody, Spaceballs articulates in plain view how the superstructure of the big budget tent pole usurps traditional studio production methods. The real-life Hollywood result may be closer to a "MegaMaid" absurdity (Longest. Ship. Ever.) than predicts the impending twenty-first century tactic identified as "franchise fascism" ${ }^{23}$ Franchise fascism is further theorized in accordance with the following tenets:

1. Fits the bill for Star Wars and most superhero tent-pole franchises

2. Is epitomized by Disney's continuous mass media and nostalgic commodity acquisitions toward global media monopolization

3. Reflects the "might makes right" fascistic ideology that finds expression in both Star Wars and Spaceballs

4. Provokes the angry masculine outcry indicative of entitled fan communities (e.g., fascist fandom) occupying digital media spaces and conquering cyber frontiers

5. Is typified by the manner in which Hollywood economics dictate decreases in individuality and auteur agency over increasingly interconnected imperial narratives of superheroic conquest, dystopian spectacle, and the lack of conclusion central to serialized storytelling under homogenous producing and directing stylistics. ${ }^{24}$

These tenets stress a tight-fisted economic cycle bent on rapid expansion by accelerated means of venture capitalism. These mechanisms are exhibited in narrative and industry practices by Lucasfilm Ltd. in the 1970s, 80s, and 9os, but arguably accelerate exponentially in the 2000s and oos through a combination of A) franchise expansion, B) toy synergy, and C) the global expansion of both once under the marketing machine-the corporate cyborg denoting empiric controldesignated by Disney. The evolutionary path of these three criteria represents the focus of the remaining sections. Their collective path charts a partial explanation for the emergence of anti- 
fan resistance. However, the essay concludes with a new prophecy to counter-balance to the dark side of anti-fan resistance.

\section{Star Wars Prequels and the Militant Alliance with LEGO}

A lot has been written about film in 1999, with a plethora of updated commentaries commemorating this momentous year of cinema's twentieth anniversary in 2019. ${ }^{25}$ Among the repeated commentaries is continuous praise for the Wachowskis's The Matrix and how this adult dystopian science fiction usurped the pop culture throne that was initially preordained for Star Wars triumphant return. That said, to allege that The Phantom Menace underwhelmed critics and audiences is an understatement. ${ }^{26}$ The film fails on numerous fronts primarily due to a clunky script and wooden performances, both results of Lucas's attention spread too thin between developing new technologies and world-building while failing to update his blind spot toward directing actors. Nonetheless, The Phantom Menace performed exceedingly well at the box office, and a new cycle began to center on the adolescent demise of the "coolest" fascist dictator the galaxy has ever seen. If Darth Vader already posed a problematic tension between loving and hating a villain due to the character's visually iconic costume, screen presence, and audibly modulated voice work by James Earl Jones, then the shift from Vader as antagonist to protagonist performed the dirty business of tricking a new generation into identifying with a tragic character in the name of media franchising and profit.

Whether or not Aiden Christensen's performance as Anakin ever achieves affective method acting or not matters less than the franchise's efficiency at world-building a prequel trilogy and multi-billion dollar property around the spiteful anti-hero turned deadly supervillain. Debuting in 1999, Star Wars made the unprecedented commodity crossover leap into LEGO form, thanks in large part to the millions of dollars already spent advertising The Phantom Menace. ${ }^{27}$ By 2005's Revenge of the Sith, Lucasfilm was no doubt already deep into planning the future of the franchise beyond the prequel trilogy's pre-credits stinger linking Episodes I-III to A New Hope and episodes $I V$-VI. Planting seeds in the middle film, Attack of the Clones, Lucasfilm as a creative organization oppositional to interpreting Lucas himself as auteur, ultimately returned to the "wartime" theme and swashbuckling intent of the Clone Wars as a backdrop for expanded storytelling. Producers shifted genres to digital animation for Star Wars: The Clone Wars (2008), an animated movie spin-off featuring the primary cast of the prequels but also retro-aging them into the middle of the 1999-2005 trilogy. ${ }^{28}$ The feature film did not perform particularly well, especially among Star Wars standards, but it did allow Lucasfilm the flexibility to merchandize new waves of LEGO Star Wars among other toy properties and tie-ins.

Similarly to Lucas striking gold with the toy rights to the original films, foregoing his director's fee as penance to the inaugural Star Wars going over budget, there is room for the strong argument that the synergistic team-up between The LEGO Group and Star Wars extended and elevated the brand dominance of both properties. LEGO took great risks by rolling out LEGOexclusive mall stores in key cities before gradually adding in most U.S. markets. This gamble occurred at a tumultuous period for brick-and-mortal shops, as staple businesses like K.B. Toys filed for bankruptcy and then folded by 2009. ${ }^{29}$ It is notable that a mere decade later, Toys "R" Us would also meet its demise, with social media digital denizens mourning the loss like culture does for renowned musicians, celebrities or maybe the pope. But LEGO succeeded, so far, and owes much of its financial boon to a shift toward production contract with pop culture franchises like 
Harry Potter, Lord of the Rings/The Hobbit, Toy Story, Pirates of the Caribbean, and more. Ironically, many of these Disney properties played second fiddle to the financial girth that Star Wars creates for LEGO, an observation that likely factoring in some small way into Disney's acquisition of Lucasfilm in 2012.

\section{The Arrested Development of Me Culture}

At this point it would be wise to anticipate and answer the intellectual concern with overselling a causal link between Star Wars, Star Wars fandom, collector culture, LEGO Star Wars, and tensions between fans, antifans, Disney Star Wars and the collector's market. LEGO is but one of many ongoing toy lines, and ire often ranges from "forced" multi-ethnic and gender representation to market oversaturation (e.g. too many films too quickly), inferior execution in the prequel trilogy, or paranoia concerning Disney's "wholesome" branding or multinational conglomerate approach to acquiring intellectual properties. The answer to all of these is a collective "yes" with LEGO Star Wars merely symbolizing one tangible arm in this commodity space race. The key understanding is how LEGO Star Wars represents a twenty-first century model of successful co-branded synergy, with both brands experiencing independent success in the late 70 s and throughout the 80s and 9os, demonstrating massive cultural appeal and financial longevity independent of one another. However, twenty-first century figures point to both brands peaking in the overlap between one another. Toy collectors regularly report how the Star Wars prequel toy lines do not maintain a strong financial value on the resale market, while LEGO Star Wars remains the company's most sought after brand directly and especially on secondary markets-including continued interest in prequel sets that may have been "dismissed" by fans during initial release, only to gain consumer interest once out of production and removed from store shelves.

If the proliferation of child-adult toys $3^{30}$ elevated and elongated the commodity lifespan of both Star Wars and LEGO throughout the twenty-first century, then the arrested development of nonending toy lines points toward a consumer focus designed to 'collect' from the consumer ad infinitum. In other words, adult consumers are put into an unconscious position to continue the accrual of Star Wars LEGO sets whether they've "grown up" or not, whether they "have kids" or don't. In ghost force terms, the spirit of capitalism thus haunts the proverbial consumer, typically male and assumedly in possession of disposable income. Like the endless battle between the forces of good and evil, the Jedi and the Sith, the Rebels versus Empire, the LEGO Star Wars commodity culture appears locked into an endless cycle based on the now symbiotic relationship between the two brands. Not unlike the War on Terror, this post-9/11 merger has no foreseeable end date and posits a micro model of its own disaster capitalism for collectors not active on the resale markets like eBay, Bricklinks, Brickset, Brothers-Brick, and other forums that help offset expenditures. ${ }^{31}$ A popular advice adage that circulates on LEGO fan sites is to "buy two, wait and sell one" in a market where LEGO, and LEGO Star Wars most notably, steadily positioned itself as a commodity more valuable than gold. Talk about a force awakening.

The downside of such lucrative profiteering by LEGO and Star Wars is that creative decisions on the narrative end and filmic side of the Star Wars brand legacy becomes equated with financial tensions, not only for producers but also with consumers. Collecting may represent a leisure activity in consumer culture for many or simply a means to getting by yet another birthday party gift for young people. For the hardcore fans, however, collecting as a methodological practice of 
fan agency represents a forceful relationship that transcends the film medium or storytelling myths in popular culture. Heavy investment in a commodified intellectual property may yield distress to the point of antagonism. If the narrative waivers with consumer interest, cultural and financial stocks ebb and flow. Capital investment can add anxiety to otherwise superfluous pop culture rituals. Life imitates art just as art imitates life. As the films have shown us, even the most powerful Jedi remain susceptible to the dark side of the force. A popular outlet for fan angst or distress remains vocalizing dissent by any means necessary, or perhaps any medium available. If 90 discourse circulated nationally and globally through fanzines, conventions, and then online message boards..$^{2}$ then the mid-oos to present have become dominated by social media algorithms that exacerbate viral memes and antagonistic sentiment.

One site where algorithmic fantagonism gains cultural legitimacy through data manipulation is RottenTomatoes.com. The film criticism website functions as an aggregate organizer of film and media data analytics. Film reviews are read against praise versus criticism, ultimately assigning movies (but also TV series and other media) a certified "fresh" (over 59\% positive) or "rotten" (59\% and under) tomato score. The site even assigns a bright red tomato emoji-avatar or pea green tomato splat as visual persuasion at a basic semiotic level. Sites like Rotten Tomatoes or Meta Critic also operate as hubs where consumers can access tickets or screen times, thanks to partnership apps like Flixster and Fandango. However, in the age of miscalled national elections, Internet-based surveys have demonstrated a weakness toward algorithmic disruption. In recent years, organized fan groups have mobilized in clearly focused efforts to "drive down" tomato scores in an effort to subvert studio films by adjusting audience interest. Because theater-going is but one of many potential entertainment markets, digital technologies and data-driven apps can authentically push or give pause to on-the-fence consumers. Fantagonistic cultural movements against the film industry seem particularly potent when studios cast female leads or reverse gender casting in remakes or reboots to popular properties.

In recent years, Hollywood at first appeared relatively naive to the mobilizing power wielded by antifan groups. The most notorious example is largely attributed to Sony losing between $\$ 70$ and as much as \$125 million on their all-star female-led cast for the Ghostbusters reboot in 2016. Circulations of various "box office reports" give large and small outlets ample feeds of click bait for entertainment readers but more importantly is the seemingly objective data spread across professional apps that do indeed point consumers toward and away from popular media. While disputes over cause point to numerous converging factors-not unlike the thesis to this essaythe economic significance negative buzz perpetuates online by dissenting "original fans" subsists. Similar subsequent efforts have been thrust upon major studio properties with female leads, including Disney-Lucasfilm's Star Wars: The Last Jedi in 2017 and Disney-Marvel's Captain Marvel in 2019.

\section{The Disney-fied Empire Strikes Back}

The relaunch of a new Star Wars saga was met with essentially universal acclaim. The Disney Monopoly approach to mergers-and-acquisitions seemed to satisfy both industry insiders-those closely rewarded by quarterly figures and publicly traded corporate value-and by fans of media texts. This honeymoon positivity can be read along two distinct lines of pop culture history. First, Disney's "Mighty" rescue and relief aid translated into the paratextual merger of the new millennium with the successful continuation of the Marvel movie franchise. While not entirely 
perfect, the Disney-Marvel formula proved to be a formidable combination of highly touted directors working under comics-friendly studio executives bankrolling A-list casts toward increasingly complicated and eventually convergent cinematic storylines. The Disney-Marvel model proved to be the stuff of legend, the ultimate Hollywood Golden Calf that satisfies domestic fans (by the generations) while also showcasing an emphasis on visual storytelling and iconic spectacle that easily translates to a multinational audience of repeat consumers. The model proved so successful, in fact, that many fear openly that this new way of business performance creates impossible standards that will forever alter the movie industry as a space for creativity. The auteur model is dead; Long live the auteur-ish franchise.

The Force Awakens opened to unparalleled success at the box office, dominating the "Christmas Holiday Season" up and through the Academy Awards timetable in late winter. Directed by J. J. Abrams, the film received universal praise for most of the first few weeks in release. Then, quietly, a small pocket of resistance started. Debates began as to whether the film could not stand up on its own because of the deliberate and overwhelming number of familiar plot points, remixed set pieces, and reliance upon its own meta-history as a component baked into the script. It was overtly zeitgeisty and in love with the nostalgia of the original trilogy. In industry terms, The Force Awakens displayed Hollywood's "trendy" maneuver synonymous now in twenty-first century productions, the "soft reboot" sequel or re-imagined "revival" that follows the long shadow of a beloved entertainment property. It was a smashing success though, and hit the marks with broad audiences so well that it surpassed the "impossible" domestic box office clout of James Cameron's Titanic and then Avatar. Audiences, perhaps aware of Abrams's penchant for strong female leads, welcomed the new hope centered on a female would-be Jedi, Rey, played by Daisy Ridley. In a surprise double-whammy, Disney released a second stand-alone Star Wars installment, Rogue One, the following winter, mimicking the former's marketing pattern with smashing success despite rumors of expensive reshoots and directorial do-si-do. More than a fictional mythos, Rogue One sported a similar brunette British imported female lead in Felicity Jones. While Rogue One shockingly went on to cross the $\$ 1$ billion dollar mark at the global box office, a kind of cultural bomb may have ignited silently just as Disney laid plans to increase the production slate and release structure for their new Star Wars universe. 33

\section{A Disturbance in the Force; or, the Fan Dissent of (Alt-Right) Rebel Scum}

The first teasers for Rian Johnson's Star Wars, Episode VIII: The Last Jedi met with heightened speculative buzz. Early gossip included "first looks" at the boldly designed new characters and settings. With the middle slot in each Star Wars trilogy something of a sacred cow-thanks to the universal praise for Irvin Kershner's The Empire Strikes Back-fan expectations met with a fever pitch alongside audiences. And yet, in a sea of Marvel movies, Fast \& Furious franchises, and a spell of continuous sequels for all ages, The Last Jedi landed at a time when audience may have suffered from un/conscious sequel fatigue. And then there is Luke Skywalker, a farmer turned freedom fighter, a white night savior capable of exacting righteous vengeance despite a homespun naïveté about the politics and structures embedded in the fascistic control of the cosmos. This guy, the man-boy earnest enough to redeem his cyborg father, who stood in linked arms with his merry band of Rebels (and Ewoks) in universal victory, smiling...was found to be living in isolation, a hermit by choice, suckling on freshly squeezed green alien udder milk, bearded and broken, miserly and contemptuous about his own spiritual journey. 
The boldness to transform a quintessential "happy ending" in the anthems of American popular culture would never have gone down well. But for fans, nay, fanatics worshipping at the Star Wars alter, the curtain was torn and the great horn sounded. If the de-mystification of Luke Skywalker was essentially perceived by white male fans in particular as something in a long line of politically correct de-powerings reflected in real-life culture, then it is no surprise that these same fans found that the fault lay at the feet of all the usual markers of the liberal agenda: feminism, cultural diversity, and honest reflection upon failed ideologies abandoned by Baby Boomers amidst the height of 8 os excess. The reflected symbols are each there, interpretable on the science fiction Rorschach that is Star Wars. After all, these stories did occur "A long time ago, in a galaxy far, far away." As did Spaceballs, by the way.

The Last Jedi, following the predestined pattern established in The Force Awakens and Rogue One, "suffers" from such "problems" as too many strong females converging upon the SW Universe too soon. Perish the thought that Luke was not immediately deified by the remaining factions spread across the remote reaches of the galaxy. Is that what audiences preferred? A future shock Utopia ruled by a celibate king with no direct heir? Have fans read King Arthur tales in full? Do they understand the fall of Camelot? Literary crises aside, there are a cavalcade of alternative "reasons" fans did not support The Last Jedi (despite its strong box office performance, surpassing Rogue One at $\$ 1.3$ billion globally).

\section{Dual-Wielding the Implications of Fascistic Fans versus Franchise Fascism}

Throughout this essay, we have been primarily interested in talking about the two haunting issues of franchise fascism and fan fascism. The top-down issue is the increasing urgency of media capitalism, the new world order as all of popular culture participates in a consumerist game of thrones, whereas the bottom-up issue involves increasingly vocal and antagonistic fan communities, organized and centralized through viral voices moving at light speed across digital media platforms. More than anti-fandom, fascistic fandom is characterized by deliberate attempts to organize, mobilize, and act against the intents of the text and its creators. It is unclear to us whether either faction acts heroically, with both parties often appearing to be guilty of the same dissent-stifling tactics. Thus, the creatives working to pacify fantagonists and satiate studio and stockholder bosses of cultural imperialism are in danger of being ground between two profoundly unartistic forces - their functions essentially reduced to those technical skills necessary to realize the "vision" generated from a bureaucratic melding of fan expectations, franchise story development, and standardized production methods.

Stuck in the rapidly vanishing middle is the auteur-a term already rife with criticism from those that see film as a collectivist medium-pulled between the multinational economics of the Hollywood machine and the unquenchable demands of an increasingly diverse populous of multimedia consumers. And thanks to the free flow platform liberated by the social media age, these consumers frequently showcase righteous mob mentality powered through deliberate and strategic campaigns for and against preferred or derided creative decisions with steep economic investment. Alongside the occasional presence of auteurs, fans (as consumers) have always had power. What has changed, in the age of social media, is the fan's ability to shape public opinion forcefully and quickly; sometimes before the object of criticism is finished, or even begun. This is especially true of genre pictures like superhero franchises and spreadable media campaigns that hinge upon the moving target ideology of nostalgia. 
Perhaps Star Wars, and the mega-franchise phenomenon it spawned, is ultimately too much of a good thing, which pop music tells us is bad enough. ${ }^{34}$ Mel Brooks witnessed the dark side of the Hollywood engine, an industry he successfully lampooned until his process became too "old fashioned" and, in a financial sense, outdated. Dark Helmet gets it right. His fascistic tendencies are juvenile, but effective for ensuring predictable outcomes. In an age of franchise fascism, there is only room for another installment in the Scary Movie franchise35, not for a movie that presents original scares. ${ }^{6}$ Despite the fanatic consumer-fan's determination to crown Star Wars as the epic of our generation (don't tell Martin Scorsese or Francis Ford Coppola), it was never actually meant to dominate the spiritual zeitgeist of popular culture indefinitely - no movie or "universe" can. It just happened to form at an ideal crossroads, a happy accident born out of genre hybridity and a reinterpreted love for remixing B-movie serials. Fascist fans have detailed, enumerated, and endlessly argued recipes for a "correct" canon and interpretive experience, fed into the profit-asart franchise machine that Star Wars successfully modeled. This hyper-aggressive productionconsumption cycle reduces the startling originality of a Luke Skywalker to the unconsciously Dark Helmet-esque Kylo Ren; a devolving circulation of commercial art imitating comedic art imitating accidental pop art.

Yet once such sub-formulas become realized, what happens next? Does the proverbial Pandora's Box close? Not likely. Instead, the blockbuster doomsday clock, powered by the fascist fan's strident censorship and the fascist franchise's accelerated production methods, inches ever closer to midnight. But then again, we all know how fun midnight movies can be. 37

\section{Bibliography}

Associate Press (n. a.). "Hollywood, creative industries add \$504 billion to U.S. GDP.”

TheHollywoodReporter.com [Website]. Retrieved from

https://www.hollywoodreporter.com/news/hollywood-creative-industries-add-504-662691, 5 December, 2013.

Bakker, Gerben. "The economic history of the international film industry.” EH.net [Online Encyclopedia]. Retrieved from http://eh.net/encyclopedia/the-economic-history-of-theinternational-film-industry/.

Banet-Weiser, Sarah. "Popular misogyny: a zeitgeist.” Culture Digitally [Online]. Retrieved from http://culturedigitally.org/2015/o1/popular-misogyny-a-zeitgeist/, 21 January, 2015.

Berquist, Yves. "Cognitive Hollywood, Part I: Data Shows Box Office economics in turmoil." Medium.com/Vantage [Website]. Retrieved from https://medium.com/vantage/cognitivehollywood-part-1-data-shows-box-office-economics-in-turmoil-411a4b22f858, 11 September, 2017.

Berry, Michael. "Chinese cinema with Hollywood characteristics, or how The Karate Kid became a Chinese film.” In The Oxford handbook of Chinese cinemas. Rojas, Carlos (Ed.). DOI: 10.1093/oxfordhb/9780199765607.013.0010. April 2013.

Bloom, David. "Hollywood's changing as fast as it ever has-Can industry lifers change too?" IndieWire.com [Website]. Retrieved from https://www.indiewire.com/2019/05/hollywoodchanging-fast-can-film-industry-lifers-change-too-120214506o/, 27 May, 2019. 
Bond, Paul. "Film, TV, other copyright industries add \$1 trillion to U.S. economy in 2012." TheHollywoodReporter.com [Website]. Retrieved from https://www.hollywoodreporter.com/news/film-tv-copyright-industries-add-657544, 19 November, 2013.

Bradley, Laura. "What busted the Ghostbusters?” VanityFair.com [Website]. Retrieved from https://www.vanityfair.com/hollywood/2016/o8/ghostbusters-box-office-loss, 10 August, 2016.

Bromwich, Jonay Engel. "Everyone is Canceled: It only takes one thing - and sometimes, nothing - for fans to dump a celebrity." The New York Times [Online]. Retreived from https://www.nytimes.com/2018/06/28/style/is-it-canceled.html, 28 June, 2018.

Bunch, Sonny. "From 'Ghostbusters' to 'Captain Marvel,' culture warriors gets box-office results all wrong." The Washington Post/Pittsburgh Post-Gazette [Website]. Retrieved from https://www.post-gazette.com/ae/movies/2019/03/14/From-Ghostbusters-to-CaptainMarvel/stories/201903140015, 13 March, 2019.

Castleberry, Garret. "Understanding Stuart Hall's 'Encoding/Decoding' Through AMC's Breaking Bad." In Communication Theory and Millennial Popular Culture: Essays and Applications. Roberts, K, \& Hickly, J. (Eds.), pp. 84-95. New York: Peter Lang, 2016.

Castleberry, Garret. Prophetic Revisionist Paratextual Ontologies: Preparing the Way for The Force Awakens. In Media Res, A Media Commons Project, 2015. Retrieved from http://mediacommons.futureofthebook.org/imr/2015/12/16/prophetic-revisionistparatextual-ontologies-preparing-way-force-awakens.

Castleberry, Garret \& William S. McMurry. "Prophetic Prophecy and Giftshop Capitalism in Mel Brooks's Spaceballs” In The Political Mel Brooks. Boerboom, S. \& Bonnstetter, B. E. (Eds.). Lanham, MD: Lexington Books, 2019.

Click, Melissa. (Ed.) Anti-Fandom: Dislike and Hate in the Digital Age. New York: NYU Press, 2019.

Click, Melissa (Ed.). The Routledge Companion to Media Fandom, $1^{\text {st }}$ edition. New York: Routledge, 2017.

Crane, Diane. "Cultural globalization and the dominance of the American film industry: cultural policies, national film industries, and transnational film." International Journal of Cultural Policy, 2o(4), 365-382. Https://doi.org/10.1080/10286632.2013.832233, 2013.

de Bruin-Mole, Megen. "Does it come with a spear? Commodity activism, plastic representation, and transmedia story strategies in Disney's Star Wars: Forces of Destiny. Film criticism, 42 (2). [Online]. Retrieved from http://dx.doi.org/10.3998/fc.13761232.0042.205, November 2018.

De Zoysa, Richard \& Otto Newman. "Globalization, soft power and the challenge of Hollywood." Contemporary Politics 8(3), 185-202. Https://doi.org/10.1080./1356977022000025678, 2010. 
Fu, W. Wayne \& Achikannoo Govindaraju. "Explaining global box-office tastes in Hollywood films: Homogenization of national audiences' movie selections. Communication Research 37(2), 215-238. Https://doi.org/10.1177/0093650209356396, 2010.

Greenway, Jon. "Fans are ruining Game of Thrones-and everything else." The New Republic [Website]. Retrieved from https://newrepublic.com/article/153961/fans-ruining-gamethronesand-everything-else?utm content, 21 May, 2019.

Hills, Matt. Fan Cultures. New York: Routledge, 2002.

Jenkins, Hannah. "Star Wars: The Phantom Menace' is to blame for modern cinema culture. Junkee.com [Website]. Retrieved from http://junkee.com/star-wars-the-phantommenace/191836, 4 February, 2019.

Jenkins, Henry. Textual Poachers: Television Fans and Participatory Culture. New York: Routledge, 1992.

Jenkins, Henry. Convergence Culture: Where Old and New Media Collide. New York: NYU Press, 2006

Jenkins, Henry. Fans, Bloggers, and Gamers. New York: NYU Press, 2006.

Jenkins, Henry. The Wow Climax: Tracing the Emotional Impact of Popular Culture New York: NYU Press, 2006.

Lieber, Chavie. "New research says secondhand LEGOs are surprisingly valuable." Vox.com [Website]. Retrieved from https://www.vox.com/the-goods/2019/1/29/18202463/legoresale-market-high-return-rate, 29 January, 2019.

Lussier, Germain. "How expectation and reality can clash in the world of Star Wars fandom." io9.com [Website]. Retrieved from https://iog.com/how-expectation-and-reality-can-clashin-the-world-of-s-1834445834, 14 May 2019.

Mahjouri, Shakiel. "'Solo: A Star Wars Story' director Ron Howard says trolls contributed to poor box office performance." ETCanada.com [Website]. Retrieved from https://www.etcanada.com/news/460106/solo-a-star-wars-story-director-ron-howardsays-trolls-contributed-to-poor-box-office-performance/, 3 June, 2019.

McLuhan, Marshall. Guttenberg Galaxy, 1962

McLuhan, Marshall. Understanding Media, 1964.

Nicholson, Amy. "Magnolia to the Matrix: Was 1999 the greatest year in modern cinema?" TheGuardian.com [Website]. Retrieved from https://www.theguardian.com/film/2019/jan/10/magnolia-to-the-matrix-was-1999-thegreatest-year-in-modern-cinema, 10 January, 2019.

Nowell-Smith, Geoffrey \& Stephen Ricci (Eds.). Hollywood and Europe: Economics, culture, national identity 1945-95. London: British Film Institute, 1998.

Pirinia, Garin. “1999: The last great year in cinema.” Esquire.com [Website]. Retrieved from https://www.esquire.com/entertainment/movies/a23803/1999-movies/, 22 July, 2014. 
Polo, Susana. "You can't change your favorite pop culture-but you can change how you engage with it." Polygon.com [Website]. Retrieved from https://www.polygon.com/comics/2019/5/18/18627983/game-of-thrones-season-8petition-rewrite-star-wars, 18 May, 2019.

Popina, Elena. "Lego collecting delivers huge market returns that beat gold, stocks and bonds." FinancialReview.com [Website]. Retrieved from https://www.afr.com/wealth/investing/lego-collecting-delivers-huge-market-returns-thatbeat-gold-stocks-and-bonds-20190118-h1a7ew, 18 January 2019.

Raftery, Brian. BEST. MOVIE. YEAR. EVER. How 1999 Blew Up the Big Screen. New York: Simon \& Shuster, 2019.

Ratcliffe, Amy. "Fully operational fandom: becoming Rey. Star Wars [Online]. Retrieved from http://www.starwars.com/news/fully-operational-fandom-becoming-rey, 2017.

Sacks, Ethan. "Congrats ghouls, your trolling of 'Ghostbusters' worked: Five reasons for the box office disappointment." DailyNews.com. [Website]. Retrieved from https://www.nydailynews.com/entertainment/movies/congrats-ghouls-trollingghostbusters-worked-article-1.2745798, 10 August, 2016.

Seitz, Matt Zoller. "What's next: Avengers, MCU, Game of Thrones, and the content endgame." RoberEbert.com [Website]. Retrieved from https://www.rogerebert.com/mzs/avengersmcu-and-the-content-endgame, 29 April, 2019.

Seitz, Matt Zoller. "What next: Marvel, the serials, and the future." RogerEbert.com [Website]. Retrieved from https://www.rogerebert.com/mzs/to-be-continued-marvel-the-serials-andthe-future, 11 May, 2019.

Singer, Matt. "Fan is becoming a four-letter word." ScreenCrush.com [Website]. Retrieved from https://screencrush.com/fans-are-bad/, 17 May, 2019.

Spross, Jeff. "Star Wars and the new economics of movie making." TheWeek.com [Website]. Retrieved from https://theweek.com/articles/595476/star-wars-new-economics-moviemaking, 28 December, 2015.

Tapley, Kristopher. "Why 1999 was the best year in movie history." Uproxx.com [Website]. Retrieved from https://uproxx.com/hitfix/why-1999-was-the-best-year-in-movie-history/, 30 April 2015.

Thompson, Derek. “The economics of awful blockbuster movies.” Quartz.com [Website]. Retrieved from https://qz.com/102902/the-economics-of-awful-blockbuster-movies/, 11 July, 2013.

Walls, W. D. \& Jordi McKenzie. "The changing role of Hollywood in the global movie market," Journal of Media Economics 25(4), 198-219, 2012. Https://doi.org/10.1080/08997764.2012.729544.

Whitten, Sarah. "Is Lego a better investment than gold?" CNBC.com [Website]. Retrieved from https://www.cnbc.com/2015/12/28/is-lego-a-better-investment-than-gold.html, 28 December, 2015. 
Wilkinson, Alissa. "Hollywood's record-busting 2018, explained: It's a booming industry with an uncertain future." Vox.com [Website]. Retrieved from

https://www.vox.com/culture/2019/1/3/18165250/2018-box-office-top-movies-hollywoodnetflix-black-panther, 3 January 2019.

Wilkinson, Alissa. "1999 was an extraordinary year for movies. 20 years later, here's what it can teach us." Vox.com [Website]. Retrieved from

https://www.vox.com/culture/2019/1/3/18157860/1999-top-movies-box-office-fight-clubamerican-beauty-toy-story, 3 January 2019.

Wood, Rachel, Benjamin Litherland \& Elizabeth Reed. "Girls being Rey: ethical cultural consumption, families and popular feminism," Cultural Studies. DOI:

10.1080/09502386.2019.1656759, 2019.

BBC America and Women's Media Centre. “Superpowering girls: female representation in the sci-fi/superhero genre. Retrieved from http://www.womensmediacenter.com/reports/bbcawmc-superpowering-girls, 31 October, 2018.

Zubernis, Lynn \& Katherine Larsen, Fandom at the Crossroads: Celebration, Shame, and Fan/Producer Relationships. Newcastle, Uk: Cambridge Scholars Publishing, 2012.

\section{Notes}

${ }^{1}$ Reproduced in several anthologies over the years, Hall's full essay appears in Culture, Media, Language, 136 (New York: Routledge, 1980). Garret Castleberry adapts and applies Hall's model to a TV case study in "Understanding Stuart Hall's 'Encoding/Decoding' Through AMC's Breaking Bad," 84-95. In Communication Theory and Millennial Popular Culture: Essays and Applications (New York: Peter Lang, 2016).

${ }^{2}$ See the suggested fan cycle posited by “The Cylce of Fandom", April 5, 2018, courtesy of HelloGreedo and YouTube, retrieved from https://youtu.be/kgy-ZZtFXAo.

3 First the Star Wars Christmas Special ruined the franchise. Then the Ewoks are "too cute" in Return of the Jedi. The Galoob Micro Machines aren't scale to size, and on and on.

4 Paul Bond reported in 2013 that copyrighted works and the "creative industry" in general outpaced "food and agriculture" exports in 2012, a figure that grew upon a similar pattern reported by the AP and the U.S. Bureau of Economic Analysis for 2011.

5 According to industry analyist Bruce Nash's Hollywood data analytics website "The Numbers", ticket sales have actually remained remarkably consistent ranging between 1.2 and 1.572 billion tickets sold annually at the box office. This data suggests that the trade press annual releases mythologizing declines in ticket sales essentially function as press releases designed to stimulate short-term economic growth from unsuspecting consumers. See "Domestic Movie Theatrical Market Summary 1995 to 2019, courtesy of https://www.the-numbers.com/market/.

${ }^{6}$ Several motivating works on Hollywood economics include Arthur De Vany's Hollywood Economics: How Extreme Uncertainty Shapes the Film Industry, $1^{\text {st }}$ edition (New York: Routledge, 2003), Edward J. Epstein's The Hollywood Economist 2.o: The Hidden Financial Reality Behind the Movies (Brooklyn, NY: Melville House, 2012), Harold L. Vogel's Entertainment Industry Economics: A Guide for Financial Analysis, $9^{\text {th }}$ edition (New York: 
Cambridge University Press, 2015), Dade Hayes and Jonathan Bing's Open Wide: How Hollywood Box Office Became a National Obsession (New York: Hyperion Books, 2004).

7 Judith Williamson's Decoding Advertisements: Ideology and Meaning in Advertising (London: Calder and Boyers, 1978) remains an unmatched masterstroke at simplifying a structuralist understanding of the complex ideological process performed on the consumer by the producer with specific emphasis on print media ads.

${ }^{8}$ Key works by Jenkins helped shape the parameters as well as the open frontiers of fan studies. Influential works that continue to spark conversation and scholarly discourse includes: Textual Poachers: Television Fans and Participatory Culture (New York: Routledge, 1992), Convergence Culture: (New York: NYU Press, 2006), Fans, Bloggers, and Gamers (New York: NYU Press, 2006), and The Wow Climax: Tracing the Emotional Impact of Popular Culture (New York: NYU Press, 2006).

${ }_{9}$ See Matt Hills, Fan Cultures (Routledge, 2002).

${ }^{10}$ Expanded theorizations of the "Global Village" trace by to Marshall McLuhan, specifically Guttenberg Galaxy, 1962 and Understanding Media, 1964.

${ }^{11}$ The "edited anthology", like the eponymously named "reader", empowers the Jedi council of modern intelligentsia to bypass the Republic Senate of would-be pay walls linked to inflated Higher Ed economics-thus carrying the torches of "knowledge" to the far-flung reaches of the academic galaxy.

${ }^{12}$ Lynn Zubernis and Katherine Larsen, Fandom at the Crossroads: Celebration, Shame, and Fan/Producer Relationships (Newcastle, Uk: Cambridge Scholars Publishing, 2012).

${ }^{13}$ See Understanding Fandom: An Introduction to the Study of Media Fan Culture (New York: Bloomsbury Academic, 2013).

14 Melissa Click (Ed.)., The Routledge Companion to Media Fandom, $1^{\text {st }}$ edition (New York: Routledge, 2017).

15 One of the most recent and rigorous contemporary anthologies, Melissa Click's (Ed.) AntiFandom: Dislike and Hate in the Digital Age (New York: NYU Press, 2019) deconstructs the halo side of Jenkins's utopic views of media usage by looking at the antagonistic worldview challenged by negativity and primarily projected through digital means.

${ }^{16}$ See the aforementioned dilemmas between commercial art and industrialized capitalism written about ad nausium by the likes of Burke, Benjamin, and other theorists of the Frankfurt School and Centre for Contemporary Cultural Studies. These foundational voices and critiques continue to manifest subsequent multiplicities among contemporary postmodern scholars and scholarship.

${ }^{17}$ Auteur theory is ripe with quality arguments both for and against it. A fuller conceptualization of this debate is covered in Robert Bresson's Notes on a Cinematograph (Griffin, J. Trans.)

(New York: NYRB Classics/Main Edition, 2011), Barry Keith Grant's Auteurs and Authorship: A Film Reader (Malden, MA: Blackwell, 2008), C. Paul Sellors's Film Authorship: Auteurs and Other Myths (New York: Wallflower Press, 2011), or Barrett Hodsdon's The Elusive Auteur: The Question of Authorship Throughout the Age of Cinema (Jefferson, NC: McFarland \& Co., 2017). 
${ }^{18}$ Especially when the stock value of Coke is tethered to the eventual inheritance of tens of thousands if not millions of employee retirement and investment portfolios.

191970 cinema is one of the most often reflected decades in film scholarship, particularly in the U.S., including Kenneth Von Gunden's Postmodern Auteurs: Coppola, Lucas, Depalma, Spielberg, and Scorsese (Jefferson, NC: McFarland Publishing, 1991), Peter Biskind's Easy Riders, Raging Bulls: How the Sex-Drugs-and-Rock'n'Roll Generation Saved Hollywood (New York: Simon \& Shuster/Touchstone, 1999), and Jeff Menne's Post-Fordist Cinema: Hollywood Auteurs and the Corporate Counterculture (New York: Columbia University Press, 2019).

${ }^{20}$ Drive-In culture is highlighted from a pair of enjoyable angles in Elizabeth McKeon and Linda Everett's Cinema Under the Stars: America's Love Affair With Drive-In Movie Theaters (Nashville, TN: Cumberland House, 1998) and Charles Taylor's Opening Wednesday at a Theater or Drive-In Near You: The Shadow Cinema of the American 70 (New York: Bloomsbury, 2017), as well as director April Wright's documentary feature Going Attractions: The Definitive Story of the American Drive-In Movie (Warren, NJ: 2014).

${ }^{21}$ Many of these pages and volumes remain archived online, displayed on websites like wishbookweb.com or social media, neither nostalgic nor irony represent mutually exclusive categories of postmodern consumption http://www.wishbookweb.com/the-catalogs/).

${ }^{22}$ James Robert Parish orchestrates a compelling blend between the personal and the professional in It's Good To Be The King: The Seriously Funny Life of Mel Brooks (Hoboken, NJ: Wiley, 2007). Veteran biographer Patrick McGilligan weaves a more populast telling of Brooks's career in Funny Man: Mel Brooks (New York: Harper, 2019) while co-editors Sam Boerboom and Beth E. Bonnstetter cultivate a polemic approach to understanding the comedy auteur's career in their collected anthology The Political Mel Brooks (Lanham, MD: Lexington, 2019).

${ }^{23}$ Of particular interest, this essay draws upon the theoretical formulation of franchise fascism presented by Garret L. Castleberry and William S. McMurry in their essay "Spaceballs as Mel Brooks Parodic Prophecy of Franchise Fascism," 187-107, The Political Mel Brooks (Lanham, MD: Lexington, 2019).

24 Castleberry \& McMurry, 2019, ibid, 100.

25 Garin Pirinia writes melancholically about "1999: The last great year in cinema" in 2014, with Kristopher Tapley close on his heels with the same argument (and nearly the same title) on Uproxx.com circa 2015. Fast-forward to the year's twentieth anniversary and a sea of media professionals, including film critic Amy Nicholson, writing for The Guardian, ask, "Was 1999 the greatest year in modern cinema?" These sentiments highlight the zeitgeisty twentieth anniversary retrospect at the heart of Brian Raftery's BEST. MOVIE. YEAR. EVER. How 1999 Blew Up the Big Screen. (New York: Simon \& Shuster, 2019), a subjective film argument that's gathered substantial momentum in light of twenty-first century tactics relying explicitly upon film franchising over original works and lesser visited adaptations.

${ }^{26}$ The Apex of negative fan sentiment may be the heavily circulated "Mr. Plinkett's Star Wars Prequel reviews" with views on YouTube in the tens of millions. See the inaugural take down "Star Wars: The Phantom Menace Review (1 of 7), courtesy of RedLetterMedia and YouTube, retrieved from https://youtu.be/FxKtZmQgxrI. 
27 The first wave production line included vintage LEGO brick models based on the original trilogy, probably the largest sales point, but Phantom Menace represented the most sets per film wave until inevitably overtaken by the nostalgia power of the originals.

28 Technically, the Clone Wars feature spins off of the widely acclaimed Clone Wars TV shorts, produced for Cartoon Network in a visual style from and akin to the team behind Samurai Jack from 2003-2005.

${ }^{29}$ It is also noteworthy that LEGO products aside, Star Wars prequel merchandizing never fully ignited with the mature collector base, a commonly spread belief circulated in shops and stores as well as through new media YouTube videos like Fact Fiend with Karl Smallwood's "Star Wars Prequel Trilogy Merchandize is Literally Worthless", retrieved from https://youtu.be/NGG9DP9RSyc.

$3^{30}$ That is to say, toys that attract child collectors but clearly are priced to move via adult consumers. See the example of the eponymous LEGO Star Wars "Death Star" which has orbited the neighborhood of $\$ 500$ (retail, not resale) since the mid-200os.

${ }^{31}$ While the term “disaster capitalism" specifically refers to $21^{\text {st }}$ Century war profiteering, it is possible to consider how Disney's monopolization of pop culture economic growth represents a soft-kill model of corporate warfare designed to incinerate competition in the name of profit imperialism.

${ }^{32}$ Henry Jenkins connects early to contemporary fan practices in his chapter "Interactive Audiences? The Collective Intelligence of Media Fans," 134-151 (Fans, Bloggers, and Gamers: Exploring Participatory Culture (New York: NYU Press, 2006). Mark Dery already theorized about antagonistic fan practices like "culture jamming" in the early 90s (Culture Jamming: Hacking, Slashing and Sniping in the Empire of Signs (San Francisco: Chronicle, 1997) just as Andre MacDonald wrote of oppositional fan disputes in "Uncertain Utopia: Science Fiction Media Fandom and Computer Mediated Communications" (In Theorizing Fandom: Fans, Subculture, and Identity (New York: Hampton Press, 1998).

33 It is note-worthy that many traditional die-hard Star Wars fans were upset at the announcement that sacred novelizations, comics lines, and other paratextual narratives were henceforth retconned from official continuity in an effort to allow Disney intellectual free reign through the simultaneous re-launching of various Star Wars comics produced under the Disney-owned Marvel imprint.

34 Or for those of us too young to remember Mark Twain's riff on Shakespeare's "As You Like It" or even Proverbs 25:16 of the Old Testament for the elders in the back.

35 And what is scarier, a parody franchise, or the increasingly laugh-less productions somehow generating just enough revenue to continue?

${ }^{36}$ This is not a direct suggestion that original horror is on the decline. In fact, the low cost of horror genre films allows space for horror auteurs to fashion their craft. Examples include Jordan Peele (Get Out, Us), Ari Aster (Hereditary, Midsommar), and Robert Eggers (The Witch, The Lighthouse).

37 Special thanks to William "Scott" McMurry for his many conversations and oral suggestions concerning the nature of fascistic fans and franchise fascism. Additional thanks to the oral feedback from those in conference at the Digital Frontiers Realizing Resistance symposium 
hosted by the University of North Texas. Additional support from Spencer D. C. Keralis, John Martin, and Christina Knopf have been constructive and encouraging as this work comes together. These feedback channels have allowed the original presentation notes to evolve into the next phase of a much larger project. In true Empire Strikes Back fashion, this essay ends on somewhat of a cliffhanger, with the appropriate follow up already underway. 